\title{
CORONAVIRUS CRISIS IN ITALY. FUNDA- MENTAL RIGHTS AND FREEDOMS: THE PRICE TO PAY FOR HUMAN HEALTH?
}

\author{
LA CRISIS CAUSADA POR EL CORONAVIRUS \\ EN ITALIA. LOS DERECHOS Y LIBERTADES \\ FUNDAMENTALES ¿EL PRECIO A PAGAR POR LA \\ SALUD HUMANA?
}

Pablo S. Cejas Romanelli ${ }^{1}$

DOI: https://doi.org/10.37767/2591-3476(2020)23

\begin{abstract}
The results of the appearance of the novel coronavirus meant for many States, the application of restrictive measures of constitutionally protected rights and freedoms, with the aim -preliminarily- of protecting the health and integrity of people. Thus, a real "emergency legal framework" was created, with restrictions on interpersonal contact, and other daily situations in the life of any society.

Italy stood out for being the first country where COVID-19 attacked with particular virulence. The first steps of the government at the end of January 2020 were aimed at preventing the entry of people from China, and soon after, put in place much more restrictive measures as the number of deceased patients increased. However, to some extent, all the imposed restrictions seemed to have been a price to be paid in order to protect human health.
\end{abstract}

\section{RESUMEN:}

Los resultados de la aparición del novel coronavirus significó para muchos Estados, la aplicación de medidas restrictivas de derechos y libertades constitucionalmente tutelados, con el objeto -preliminarmente- de proteger la salud e integridad de las personas. Así, se dio paso a la creación de un verdadero "sistema jurídico de emergencia", con restricciones al contacto interpersonal, situaciones por demás cotidianas en la vida de cualquier sociedad.

Italia se destacó por ser el primer país donde el COVID-19 atacó con particular virulencia. Los primeros pasos del gobierno a finales de enero de 2020 tuvieron el objetivo de impedir el ingreso de personas provenientes de China, para poco después disponer medidas mucho más restrictivas a medida que el número de pacientes fallecidos aumentaba. Sin embargo, en algún punto, las restricciones impuestas se presentan como el precio que se debió pagar a cambio de la salud humana.

1 Abogado (UNC), Escribano (UES21), Maestrando en Relaciones Internacionales (CEA-UNC). Investigador del programa "Globalización, Gobernanza, Derechos (humanos) y Bienes Públicos” (CEA-UNC). Presidente de la Fundación Instituto para la Investigación Jurídica y Social (Córdoba-Argentina). pablocejasromanelli@gmail.com - pcejasromanelli@injus.org. ORCID iD: https://orcid.org/0000-0001-6069-0187 
KEY WORDS: COVID-19; Italy; Emergency declaration; Fundamental rights and freedoms; State of emergency and public health.

PALABRAS CLAVE: COVID-19; Italia; Declaración de emergencia; Derechos y libertades fundamentales; Estado de emergencia y salud pública.

\section{Introduction.}

The situation generated from the appearance of the novel coronavirus (COVID-19), the repercussion and impact at the global level has been undeniable. In Europe, the first worrying focus of the virus took place in Italy. Soon after, the results were seen in the rest of the continent and the world. This represented a huge challenge for healthcare systems worldwide, and some problems in this regard could be therefore highlighted, and maybe otherwise would not have been equally noticeable.

But the virus, as a health problem, brought with it an impact on personal rights and freedoms in most of the States where emergency measures were taken. Such restrictions functioned as the price to be paid to protect the lives of citizens, the security of countries, and state sovereignty.

At the same time, once again the porosity of the state borders was shown, which, as in the case, were unable to put a decisive brake on the spread of the virus without meaning to keep rights unchanged. The purpose of this article is to address some of the problems posed by the exceptional measures adopted by the Italian government since the appearance of the first cases of COVID-19.

In order to address the topic it worth the mention of some aspects that illustrate the overall situation of the country. Therefore, this article is organized in three main parts. The first one presents some facts about the country, emphasizing the geographical and economical aspects, followed by some institutional highlights.

The second one presents the legal grounds for the most relevant measures adopted during the first stages of the situation, starting with the emergency declaration and the relationships between the constitutionally recognized rights and liberties and their affectation by the set of governmental measures. Also in this part, considerations about health care as a fundamental right and the consequences that derive from that are addressed, while concludes with highlights of two jurisdictional rulings that were emitted amid the COVID-19 crisis about measures set in force by regional governments,

Finally, the third part, draws special attention to the correlation between health as a security issue (and its securitization) while at the same time, exposes the responses from two international organizations, the World Health Organization and the European Union, to the crisis management.

\section{Italy, a general outlook}

It is useful to first make a general description of the country in order to seek to understand some reasons that could have been key in the spread of the virus and in the 
affectation of large number of people in some regions. The first part will expose some geo-economical information, as well as information regarding population distribution (in ages, and geographical regions); while the second part will provide an outlook of the legal and constitutional framework of the country, emphasizing the national, regional, provincial, and municipal distribution of powers and competencies.

Italy is a country that is geographically surrounded by the Adriatic, the Tyrrhenian, the Ionian and Ligurian Seas and that limits its northern part, with France, Switzerland, Austria and Slovenia. It has a total population of slightly over 60.3M people (ISTAT, 2020a), unevenly distributed between the North (27.8M, 46.2\%), the Center $(12 \mathrm{M}, 19.9 \%)$ and the South and Islands (20.4M, 33.8\%). At the same time, people with ages from 55 years old and over, considered as elderly by the National Statistics Institute, represent around 45\% of the total population. (ISTAT, 2020f) This situation is not just another fact, and as will be seen later, it has a bearing on the development of subsequent events in the way that they were, being precisely this population band, the one with higher life risk and at the same time, the one demanding more health care services.

As previously said, the Italian population according to the official data from the National Statistics Institute, is distributed geographically with certain predominance in the northern regions of Aosta Valley, Piedmont, Liguria, Lombardy, Emilia-Romagna, Veneto, Friuli-Venezia Giulia and Trentino-Alto Adige. To illustrate this situation, it is graphic to show which proportion of the total population live in this area and which are the investments in health care, and compare them with the southern regions of Italy.

In Piedmont, for example, $13.5 \%$ of the population is 75 years old or over that age, and the average investment in health care is around 1,933 euros per capita. In the case of Veneto, the population of 75 years old or over is around $12 \%$ while health care investments are around 1,954 euros per capita. Finally, in Lombardy, 11.7\% of the population is 75 years old or over, and the healthcare related investments are around 1,977 euros per capita. This situation contrast with the regions of Apulia, Sicily or Calabria, where the population over 75 years old is in all cases slightly inferior to $11 \%$, while the investments in health care are around 1824, 1709, and 1847 euros, respectively. (ISTAT, 2020e)

As it will be later shown, this distribution, ages and proportions had a direct relevance in the development of the facts as they did, especially in the northern regions.

Regarding the national internal economy in midst of the "COVID-19 emergency" context, the Italian GDP grew $0.3 \%$ during 2019, while the most developed regions in terms of growth were the ones located in the North West of the country (around 0.5\%), whereas the Central and Southern regions experienced a growth around $0.2 \%$. This tendency was maintained during the first trimester of 2020, where the impact derived from the lockdown determined a contraction of $-5.3 \%$ in the GDP, where the Industry stricto sensu was the most affected one $(-8.6 \%)$ followed by the construction $(6.2 \%)$ and the sector linked to tourism -hotel, services, restaurants- observed a contraction of $-9.3 \%$. The family's expenses diminished up to $-6.6 \%$, while the investments fell around $8.1 \%$. (ISTAT, 2020c) By the second trimester, the ISTAT report published on July 31st 2020, shows that GDP experienced a negative a growth of $-14.3 \%$ (ISTAT, 2020d), mostly due to the cumulative causes of the already ongoing crisis and the challenge that COVID-19 meant for the national and World economy. 
In the political field, the country is organized according to the Constitution as a democratic Republic (art. 1, Italian Constitution) and on the basis of the principle of decentralization of the distribution of the powers of the State between a centralized authority and the territorial entities. Art. 114 of the Constitution provides that Italy is made up of Municipalities, Provinces, Metropolitan Cities, Regions and the [national] State. Each of these, and of course the National State, have autonomy which allows them to give themselves, a statute, powers and functions as also established by the Italian Constitution.

This autonomy that they have, finds expressions or externalizations of diverse character: a) on the one hand, a statutory autonomy, where they can organize the powers and attributions in the way that they deem convenient through a statute, finding a limit however, in the national Carta Magna; b) administrative-normative, since they can dictate the administrative acts that they deem necessary to attend to the purposes that are inherent to it, in addition to other norms that take the form of regulations or laws (in the latter case, only the regions); c) political, while the election of members of the regional, provincial, or communal government does not necessarily have to coincide with those of the national government; and finally, d) financial, which gives them the possibility of raising the necessary funds to start up their functions, by defining taxes of various kinds.

From this general outlook, the situation that arrived with the COVID-19 emergency draws special attention to the most affected locations: the northern part of Italy, where the highest income and development is concentrated, but also where the highest number of elderly live. However not only this is a considerable fact, but also that the highest number of industries are located in the North and due to the lockdown, this part of the country was specifically from the government's measures which lead (and might continue leading) to a deepening of a crisis that has not stopped since the last decade.

\section{The different stages of COVID-19 in Italy. Facts and legal framework}

The presumably first case of COVID-19 in Italy was detected at the end of the month of January 2020 in the city of Rome to a couple of tourists of 66 and 67 years of age, of Chinese nationality who, coming from the Chinese province of Wuhan. They were in the Italian capital having arrived in the country at the airport of the city of Milan on January 23rd, 2020. The people were hospitalized and then according to official government sources, once stabilized, they were discharged.

Soon after January, some governmental responses emerged to the situation, with two ordinances from the Health Ministry (which will be treated separately) until the declaration of emergency at the Minister's Council on January 31st. The impact of the measures, beyond situations of political content and possible diplomatic conflicts as a result of the adoption of a decision that a priori could have been considered discriminatory and even xenophobic, also brought with it a host of political, social and economic consequences of enormous impact. From this measure, the different governmental spheres or strata, each within the competency framework outlined by the Italian Constitution, gave rise to a kind of "normative framework of the COVID-19 emergency" that includes aspects of the most varied order.

Apart from the normative field, the situation in the different regions of the country 
showed a significant heterogeneity. To describe this, the number of deaths in the regions of Lombardy, Piedmont, Emilia-Romagna and Veneto, all added, resulted in 141.172 persons, representing $70.6 \%$ of the total deaths in the country. (Civil Protection Department, 2020)

The number of cases of COVID-19, from January to May, 2020, showed a prevalence of feminine gender cases (54.2\%) with ages between 60 and 64 years old. The $1 \%$ of the COVID-19 diagnosed cases, corresponds to the range between 0 and 14 years old, of both sexes; while the $33 \%$ of the cases were detected in people over 75 years old. (ISTAT, 2020b)

Following the government declaration of "zonification" of the country, classifying them into high, medium and low-diffusion zones, the great majority of deaths linked to COVID-19, were verified in the "high diffusion zone" (80\% of the cases), while only a $14 \%$ of the cases in the "medium" and the remaining 6\% in the "low". (ISTAT, 2020b) As by May $31 \mathrm{st}, 2020$, the total of deceased people was 32,981 with a previously diagnosed COVID-19 case, from which the $1 \%$ was in the age range of 0 to 50 years old.

Therefore, the primary and at first sight most evident conclusion, is that the virus affects with a particularly mortal effect to people over 55 years old, which represent as said before, around $45 \%$ of the Italian population. This first premise permits to see that, in combination to the low natality rate that the country has been experiencing in the last 10 years, the impact in population (loss) is significant, compared to any other year in recent History.

But at the same time, the potential impact for the healthcare system that had to admit thousands of patients with high risk of death is considerable, mostly because of the unprecedented situation. The total of detected cases from January to July 31st, 2020, was 247.537 , which represents less than $0.4 \%$ of the Italian population.

\section{Health emergency from a Constitutional perspective}

After the World Health Organization (WHO) declaration of Public Health Emergency of International Concern (PHEIC) on January 30th, 2020 (WHO, 2020), the Italian government declared the state of emergency by resolution of the Council of Ministers (CM) on January 31st, 2020 taking into consideration the health risk linked to the onset of diseases that can be derived from viral agents such as, in the case, COVID-19. But soon before this, the Health Ministry emanated two ordinances with severe measures affecting the circulation in the country. The first one, on January 25th, 2020 so called "Prophylactic measures against the new Coronavirus (2019 - nCoV). (20A00618)", stated that "(a)Il passengers disembarking in Italy and coming with flight directed by countries including areas where one has occurred sustained autochthonous transmission of the new Coronavirus (2019 - nCoV), airlines, companies and entities, public and private, which manage airport airports, are required to comply with the health surveillance measures in place, as well as further ones adopted by the competent offices of the Ministry of Health."

Afterward, on January 30th, the ordinance named "Prophylactic measures against the new Coronavirus (2019 - nCoV). (20A00738)" adopted a much more restrictive disposition regarding this circulation freedom, with special concern to the incoming flights from China, which were prohibited. In its first article, the Health Ministry stated that "(i)n order to gua- 
rantee an adequate level of health protection Air traffic from China as a comprising country is prohibited areas where a sustained autochthonous transmission of the new Coronavirus (2019 - nCoV)."

Arrived to this point, the measures previous to January 30th, i.e., before the emergency declaration, where purely sectorial and the situation changed drastically when this emergency was declared at a national level. (Luciani, 2020) However, in the CM disposition that declared the emergency, the Council decided to invoke the provisions contained in the Legislative Decree n. 1, from January 2nd, 2018 (Civil Protection Code or CPC), particularly in art. 7, paragraph 1, letter c), and art. 25 , for the purpose of carrying out protection activities.

Regarding the specific case of COVID-19 crisis and the following emergency declaration, the resolution adopted by the CM, specifically invoked the the art. 7, paragraph 1, letter c) of the CPC, qualifying the event that justifies the emergency declaration due to its connection "[...] with calamitous events of natural origin or deriving from the activity of man which in due to their intensity or extent they must, immediately intervention, be faced with extraordinary means and powers by use during limited and predefined periods of time pursuant to of article 24."

According to the Civil Protection Code, art. 5, the President of the CM (commonly referred as Prime Minister), has the power to emanate ordinances regarding civil protection according with art. 24 of the same Code. The last mentioned article provides that, once verified the events or their imminence, the CM upon its President proposal, can declare the state of emergency in a nationwide spectrum or specific parts of the State, determining the duration and territorial limits, and also the economic funds that might be applied to the emergency. However, in this matter, there are certain limits that cannot be surpassed. For example, art. 24.3. CPC sets the maximum duration of the nationwide emergency, which cannot exceed twelve months and admits only one prorogue for the same period. Therefore, the maximum length, according to law, is twenty-four months.

Once arrived at the state of emergency declaration, its constitutional examination, leads to the conclusion that it does not have a specific regulation at the constitutional level, but follows the logic that the Constitution provides for the declaration of the "state of war". In this sense, article 78 of the Italian Constitution provides "(I) and Chambers deliberate the state of war and confer the necessary powers on the Government" at the time that art. 87 (which contains the faculties of the President of the Republic) provides that the head of state declares the state of war deliberated by the Chambers. In the harmonious interpretation of these provisions, the national emergency status can be found.

When speaking about emergency, it is possible to say that implies "an unforeseen combination of circumstances or the resulting state that calls for immediate action" or "an urgent need for assistance or relief" (Merriam Webster, 2020), and more technically, consists of "partially unexpected events by the constitutional order and by the ordinary legislator, which require a provisional derogation to the legal system in force" (Rolla, 2015) In this regard, the distinctive point is the temporariness, during which several dispositions are abrogated but not in a definitive way, but as long as the declared emergency lasts. These abrogations may cause, however, important impacts on the civil liberties and rights, guaranteed not only by the Constitution, but also by the complex legal system which includes supra- 
national and national norms in this sense.

The distinctive aspect of a temporaneous suspension of certain dispositions that are part of the legal order of a State (including multi-level norms), faces also a limit in the same legal order. An alteration exceeding the scope for which special powers have been granted in the emergency framework, leads to a permanent alteration of the legal system. One of the most common and important consequences of this state of emergency, is the possibility to rule by the means of Decree-Law.

In any case, the situation resulting from the COVID-19 emergency was in recent History, one of the most exceptional examples that the Constitutionalists may not have foreseen at the time of shaping the basal law of the country. This unprecedented reality that has affected the whole globe, also required an interpretation of the norms that could allow to guarantee two cardinal points: primus vivere, that is to say, first to live, and salus rei publicae, considering health as a public concern.

For this same reason of lack of precedents, is that the shaping of the norms that outcame in the framework of the extraordinary times, require also to be understood as working with the other constitutional rights and liberties which however, have been seriously affected. It is problematic to say that the right to be healthy has a price which cannot be measured in an amount of money, but in rights and liberties. This seems to have been the situation Italy experienced, like many other countries in the World: restrictive measures regarding interpersonal contact, specially gatherings in public places, movement and permanence, the "stay at home" phrase tirelessly repeated by authorities, the closing of schools, the impact of people losing their jobs, are just some examples of the price that had to be paid in order to "flatten the contagions curve", another well spread phrase.

One of the most relevant questions that can be made is under which conditions a person can be restrained of almost all constitutional rights and liberties to protect only one. Preliminarily, it can be stated as it was, even in the case that the governmental measures also aimed to protect other rights, and many dispositions like tax relieves or temporary state-paid salaries of private employees, were set in force in order to contribute with some companies and discourage them from mass layoffs of employees.

\section{Healthcare protection and COVID-19}

Regarding people's health protection, the Constitution also provides in art. 32 that "(t) he Republic protects health as a fundamental right of the individual and an interest of the community, and guarantees free care to the poor. No one can be obliged to a specific health treatment except by law. Under no circumstances can the law violate the limits imposed by respect for the human person." At the same time, this constitutional disposition must be read with an harmonious interpretation with the Universal Declaration of Human Rights, the European Union Charter of Fundamental Rights, which will be separately addressed, and other international treaties in which Italy is a signatory part .

From this article, it is possible to understand how health is considered at the constitutional level: the State interest is to protect health considering it as a fundamental right, with two projections: an individual one and a collective one. The second paragraph, underlines the autonomy of the individual regarding health treatments which cannot be compe- 
lled but only by law, completing this disposition with the third paragraph which enhances the respect for the human person when dealing with health treatments.

The Universal Declaration of Human Rights, states in art. 25 that "(e)veryone has the right to a standard of living adequate for the health and well-being of himself and of his family, (...) and medical care and necessary social services, and the right to security in the event of (...) sickness, disability, (...)." (UN, 1948) At the same time, the European Union Charter of Fundamental Rights recognizes in similar way the right to health care, stating that "(e) veryone has the right of access to preventive health care and the right to benefit from medical treatment under the conditions established by national laws and practices. (...)." (EU, 2020)

The Declaration of Alma-Ata of 1978 on Primary Healthcare, reinforced the consideration of health as a comprehensive state of being, not only represented by the absence of disease or infirmity, but a physical, mental and social wellbeing, and at the same time, recalled on a consideration of health as a fundamental human right. The scope of it is to achieve the highest possible level of health and in a worldwide logic.

At this stage, it can be peacefully said that healthcare is, according to different sources of law, binding and customary, is a fundamental right. This conclusion, however, leads to further questions: what are the implications of considering healthcare as a human right? How is that a right or freedom (i.e., to receive healthcare treatments) became an obligation? How this right accommodates in the spectrum of several other civil, economic and social rights recognized at different normative levels?

Trying to address the first of these questions, it could be said that this right has at least another two different projections: one centered in freedoms, such as the right to decide about one's own body, and another centered mostly in entitlements, as the right to receive treatments, and protection to health. (Biglino \& Olmo, 2012:23-24) Assumed the healthcare right as a human or fundamental right, it implies that the States have an obligation both internally and internationally to observe all the steps needed to guarantee to the people the access to a certain right.

In this sense, States face challenges when trying to observe this mandatory rule. On the one hand, the accessibility to the right, which in the case of healthcare, means having enough resources (economic, financial, human, infrastructural, etc.) to attend to the medical attention that patients might demand. Considering the outstanding requirements that COVID-19 crisis showed, not every country had the possibility to answer these demands successfully, especially if those came simultaneously. Therefore, many States enacted several norms requiring social distance measures, with different grades of strictness, driving some of them to severe quarantine situations, where the normal activities in any society were abruptly interrupted.

Italy enacted in 1978, Law 833 from December 23rd, creating the National Sanitary Service (Servizio Sanitario Nazionale) with the purpose of protecting the healthcare right as an individual fundamental right in interest of the community. As detailed by art. 1 of Law 833/1978, the national health service has the responsibility for the "(...) promotion, maintenance and recovery of the physical and mental health of the whole population without distinction of individual or social conditions (...). The implementation of the national health service is the responsibility of the state, regions and local territorial bodies, ensuring the parti- 
cipation of citizens." Therefore, following the structure of Italy as a country, the healthcare service is not only in the hands of the national State, but is a shared responsibility with the Regions and local authorities.

Secondly, stating that to receive health care is a right every person has, the question that comes to the analysis is if there are any cases or conditions in which this right can be transformed into an obligation. Therefore, the autonomy of the person and the individual right to decide whether to receive a health treatment or not; can be converted into an obligation. The constitutional disposition remarks that only in the case that a treatment is turned into mandatory by law, this conversion might take place.

Hence, when can the law determine the mentioned passage from right to obligation of the patient? An answer to this question might be found in the consequences that the health condition or disease might cause. When an impact in the public health is feasible to be configured, therefore there is a need to treat that problem. In this sense, there is a much more transcending view, over the individual towards the society; where the constitutional dispositions related to the classical civil liberties, need to be interpreted in an axiologically way equating to them, the social rights related to the overall development of the human being.

Must be understood that the person itself, isolated from the community, is not the subject of the constitutional tuition, but on the contrary, it is the human being in a constant social relation with others. Especially this social interaction, the community sense, and the idea of public common good, acquires relevance in the health emergency raised due to COVID-19.

On the other side, it is possible to find the rights or freedoms, which usually do not contain a sanction in the norm that recognizes it or grants it. However, it is possible to find a punishment in this kind of legal norms in the case of violation, in a way to protect its observance. This is the field of subjective rights, the ones that confer to people, a liberty, attribution, freedom to perform a conduct (Nino, 2003:67-70) while at the same time has positive expression (the right to do something) and a negative one (the right to refrain from doing something). The fundamental right to healthcare, in the Italian constitutional wording, represents both of this: from one side, the State recognizes the right and protects it, while from other; no one can be compelled to receive a treatment against his or her will. But this is not, once again, an absolute rule, since it finds a limit: only the law can impose a treatment.

The passage from a right or freedom to an obligation, recalls what Hebert L.A. Hart in his book The Concept of Law underlined when describing the obligation. Therefore, a rule needs social pressure, which is considered important for the social system preservation, and at the same time implies (or can imply) a sacrifice in the person who has the obligation in the case of a conflict between the conduct wanted and the one prescribed as mandatory. This is what Hart called primary rules: an obligation with a sanction in case of transgression. (Hart, 1961:99; 125-146) In similar tessiture, John Austin defined the juridical norms, with an accent in the punishment in case of deviation, while Hans Kelsen did similarly when considered that all juridical norms, to be one, has to have a sanction, and if otherwise, it represents only an antecedent of a juridical norm. (Nino, 2003:78) 
In the interpretation of this passage from a subjective right to an obligation, on the one hand, a utilitarian fundament can be extracted, which is the tuition of the wider and superior interest of the community to protect all its members from the threat that a virus could mean, especially when that threat represents a risk of lives loss; but at the same time, has a deontological explanation which finds support in the social solidarity principle receipted by the Constitution in art. 2. Remains however unattended the eventual negative consequences that the treatments caused (or could have caused) to patients that mandatorily received them; and who and to what extent, someone may be accountable for these negative effects of the treatments that were administered to patients, even against their will due to the legal obligation to prevent contagions. The questions will remain unanswered until some sort of solution is found, being it a vaccine or an effective well-proven treatment.

Emphasizing this, as previously addressed, the unprecedented situation led a numerous normative which intended to be tuitive of human life against an unknown outcome of the facts. This situation needs to be underlined, since many of the legal dispositions adopted by governments worldwide, were following the events contemporaneously to its occurrence, in a kind of trial and error logic that, unfortunately, had severe and negative outcomes.

To answer the third of the proposed questions, about how the right to healthcare in this context works with other rights and liberties recognized by the Italian legal framework, the following section will address in a detailed way.

\section{Fundamental rights and liberties: a utilitarian weighing?}

Another aspect that has been well discussed in the doctrine is the way in which several individual liberties have (presumably) been affected by different measures adopted by the government. And, to some extent, how those different rights, liberties, and guarantees were valued in this context.

The Italian President signed, on February 23rd, 2020, the Decree-Law 6/2020, providing a series of possible measures to be adopted by the competent authorities in order to avoid the spread of the virus in the cities where at least one person was tested positive for COVID-19, developing a list of possibilities. Among these, it is possible to highlight the prohibition of leaving the municipal area for the person who tested positive or his/her relatives or cohabitants, as well as to enter into the territory; the suspension of events of all kinds, public and privates; suspension of museum openings and educational trips; the application of quarantine measures for individuals who had contact with positive cases, among other possible dispositions.

When following the mentioned Decree-Law authorized measures, it seems striking the way they were exposed, due to the redaction of its dispositions, that leads to think that the Constitution was being followed in the Second Part (Rights and Duties of Citizens) in order to negate every single right, guarantee, and freedom.

The Constitution recognizes, soon from art. 2, the personality principle, stating that " $(t) h e$ Republic recognizes and guarantees the inviolable rights of the person, both as an individual 
and in the social groups where human personality is expressed. The Republic expects that the fundamental duties of political, economic and social solidarity be fulfilled."

As a consequence, many other individual rights and principles are consecrated in the Fundamental Law of the country, such as the equality principle (art. 3), the right to work and to pursue a gainful activity (art. 4), and the rights and duties of citizens, in arts. 13 to 54. In the COVID-19 emergency, many of these rights and duties have been to some extent, affected by the extraordinary dispositions adopted by the different institutions of the government. But in order to honor the need to be brief, it is useful to underline some of the ones that had a particular affectation.

What is true, on the other hand, is that when an emergency situation comes up, from a strictly formal point of view, the legitimacy of the normative emanated and the procedures related to it, sometimes tend to be hard to follow or defend. (Luciani, 2020:2-4) As stated before, part of the doctrine finds in art. 2 of the Italian Constitution, at the time of consecrating the solidarity principle and the need to sacrifice some liberties to achieve a wider and public interest, a possible supporting reason for the adoption of such decisions (Licciardello, 2020:3) which however need to follow at all times, a proportionality between restriction and the necessity which is invoked to do so.

Some extreme versions, if they could be called this way, go further and admit another means that might cast doubt the proportionality principle. In this sense, argue that the State could not be a mere viewer of the situation, expecting it solves itself at some point, but has to put into action as many tools, strengths, means and power at all costs, if necessary. (Miele, 1936)

The Italian Constitution (art. 13) provides the inviolability of personal liberty, with exceptions admitted only by law: restrictions ordered by a jurisdictional authority grounded in law, and extraordinary measures adopted by the police but with a duly communication to the competent jurisdictional authority. This article gives special attention to the arrest, coercion, and other means of physical restrictions, protecting the citizens against any physical restriction that could be imposed and therefore, limit the personal human circulation in the territory.

Regarding the different ongoing processes, with special relevance the criminal proceeding, the Decree-Law 18/2020 from March 17th , provided in art. 83.1 the postponement of criminal hearings before the Courts until April 15th, 2020, and by means of art. 83.17, the possibility to suspend (upon decision of the judiciary supervision authority) the granting of the semi-liberty benefits, until May 31st, 2020. In this framework, the Penitentiary Administration Department, by Note n. 95907 of March 21st, 2020, informed to the Directors of different prisons in Italy, a list of diseases and health conditions that should be informed, as well as other information that could be valued with the purpose of conceding home detention benefits. This disposition caused a huge debate in the press and some sectors of doctrine, and for that reason the Head of the Department was removed and the person who substituted him, provided by Note n. 209709 from June 16th, 2020, the suspension of the previous measure.

Therefore, the situation resulting from the COVID-19 emergency, acquired special relevance regarding the due process of law, and the administration of justice, with particular 
concern to criminal justice. In this regard, some heads of criminal organizations were released from prison, turning their sentences into home detention, a situation which has significance in Italy, especially after all the processes that were followed against the mafia to get their leaders imprisoned.

In the second place, art. 16 of the Constitution provides the circulation and permanence liberty of the citizens. In this sense, the disposition states that "(e)very citizen has the right to reside and travel freely in any part of the country, except for such general limitations as may be established by law for reasons of health or security. (...) Every citizen is free to leave the territory of the republic and return to it, notwithstanding any legal obligations."

As can be understood, every citizen has this individual liberty to circulate in the territory of Italy, without limits, unless those are set a) by law and b) obey reasons of health or security. In the case of COVID-19 emergency, the legislation emerged after the declaration of emergency, gave a fertile soil to several restrictions to these liberties consecrated in arts. 13 and 16 .

From this disposition, it is clear from the constitutionalist perspective that any sort of limits posed over the liberty needs to find a support into a primary source of law -a law stricto sensu- or a secondary source, like an act that has the same value as a law. In this last case, it is mandatory to examine the congruence between the act adopted and the principle of the rule of law. The compatibility between both will result in the legitimacy of the normative disposition containing any sort of limit to the fundamental rights constitutionally recognized.

The Decree-Law 6/2020 from February 23rd that resorted different limits, contained particular dispositions about the movement and permanence in the Italian territory. Therefore it authorized the adoption of measures such as the prohibition of leaving a regional or municipal territory, and/or the ban to entrance into a municipality or region. Later, the DPCM from March 1st, 2020, individualized the prohibitions in providing the ban to any circulation to and from the Region of Lombardy "(...) and in the provinces of Modena, Parma, Piacenza, Reggio Emilia, Rimini, Pesaro and Urbino, Alessandria, Asti, Novara, VerbanoCusio-Ossola, Vercelli, Padova, Treviso and Venice (...)", with the exception of a well proven reason given to working duties or any health issue that justifies any circulation.

Another individual right seriously affected by the governmental measures, was the right to assemble recognized by means of art. 17 of the Constitution, which states that "( $(c)$ itizens have the right to assemble peaceably and unarmed. No previous notice is required for meetings, including those held in places open to the public. In case of meetings held in public places, previous notice shall be given to the authorities, who may prohibit them only for proven reasons of security or public safety."

But this right not only refers to the assembly in sense of protest, for example, but also any other gathering of people with some purpose (i.e., football match, meetings in bars, conferences, stadiums, concerts, etc.). Many of these examples, as can be preliminary seen, have a severe impact on the economy. As per the results of the lockdown, many public places which were mainly related to people reunions, had to close their doors without any kind of certainty regarding the opening dates.

Once again, the previously mentioned DPCM from March 8th, banned the public sport 
events, retaining that only the training for professional sports players were admitted, both in open and closed spaces, but without the presence of the public. The main aim of the residual authorization was probably justified in the (at that moment) upcoming events related to the Olympic games that were later cancelled.

Other banned sort of reunions that provided the mentioned DPCM, were the cultural ones, gaming events and religious celebrations. However, on these last ones, provided that cult celebrations would only be admitted if considering the location of it, a distance of one meter was able to be kept.

Therefore, even having in mind that the exercise of cult and the liberty of assembly are two different fundamental rights, both combined a special character regarding the massive celebrations (such as the Holy Mass, for example). Thus, it leads to examine the other affected right, related to cult profession in public and private places, as guaranteed by the Constitution in art. 19. It provides, that "(a)nyone is entitled to freely profess their religious belief in any form, individually or with others, and to promote them and celebrate rites in public or in private, provided they are not offensive to public morality."

In this case, religion or cult profession can be considered from two different perspectives. From an internal one, which has not an external outcome or manifestation, and that implies a mere exercise of beliefs, it could be at first sight said that has not any kind of affectation. However, from an external perspective, religion and cult also implies the development of rites usually open to the public and held in public places such as churches, temples, mosques, etc. From this last point of view, the right was obviously affected since gatherings were banned by authorities due to the risk of contagion, and if not banned at all, requested to maintain a security distance between people not compatible with the nurture of those reunions.

Mostly for similar reasons, laying in the fact that gatherings with numerous people represented higher risks of contagion, also the right to education/instruction was also affected by means of the governmental dispositions. The Constitution states regarding this in art. 33 that "(t)he Republic guarantees the freedom of the arts and sciences, which may be freely taught. The Republic lays down general rules for education and establishes state schools of all branches and grades. (...) Higher education institutions, universities and academies, have the right to establish their own regulations within the limits laid down by the law." On the other hand, art. 34 provides that "(s)chools are open to everyone. (...)".

The already cited DPCM from March 1st, that provided the suspension of all didactical activities in a face-to-face mode and in every level (primary, secondary and higher), leaving however open the possibility to continue with the activities from a remote way (elearning). This situation led to a completely new way of teaching for many teachers and professors at all levels, since not in every school or University of the country there was a remote learning platform ongoing ready to be used on a daily basis and only way of administering classes.

Besides the evident right to access to education that was, at least, compromised due to the tools the Government adopted, also the right to work in the head of the staff of schools and Universities was seriously affected. 
Concerning the right to access to education, the situation did not envisage many needs related to this, particularly the ones linked to access to the technology gadgets and knowledge about how to use them. The virtual classes were in many cases held through platforms not necessarily developed for educational purposes, and this meant a challenge for teachers and students at the time of continuing their activities. As stated before, it also assumes that every student has at home, one PC per person/student to follow the classes.

The Ministry of Public Instruction, by means of Note 288/2020 of March 17th, expressed that by "distance learning" it is understand the "direct or indirect connection, immediate or deferred, through videoconferences, video lessons, group chats; the reasoned transmission of teaching materials, through the uploading of the same on digital platforms and the use of class registers in all their communication and teaching support functions, with subsequent re-elaboration and discussion operated directly or indirectly with the teacher, interaction on truly digital educational interactive systems and apps (...)". In this note, it also addressed the question about the access to the technological resources needed for this purpose, allowing the educational organizations to lend the devices already present at schools, or to request subsidies from the Public authorities for these means. It has to be considered that, according to the official statistical institute in Italy, $33.8 \%$ of the Italian families do not have computers and tablets at home, while only the $22.2 \%$ have one device per person at home. (ISTAT, 2020g)

The situation of workers, not only at scholastics levels, but in general, was another considerable preoccupation, and the COVID-19 emergency meant also serious concerns for the productive and service sectors that implied activities usually performed in a face-toface fashion. The right to work and develop any other gainful activity is recognized in the Italian Constitution in article 35 and 36, the first of which provides that " $(t)$ he Republic protects work in all its forms and practices. (...)", while art. 36 states that "(w)orkers have the right to a remuneration commensurate to the quantity and quality of their work and in any case such as to ensure them and their families a free and dignified existence. Maximum daily working hours are established by law. Workers have the right to a weekly rest day and paid annual holidays. They cannot waive this right."

As said before, the merge in the case of education from an onsite-based activity to a home-based one, also affected the work. Many workers, from the most various fields, were sent to work from home with a modality that was known as "smart working" or "lavoro agile". This relatively new way of working, was born with Law 81/2017, which defined it as the "mode of execution of the employment relationship established by agreement between the parties, (...), with possible use of technological tools for the performance of the work activity (...), partly inside company premises and partly outside without a fixed location, within the limits of maximum duration only of daily and weekly working hours (...)" However, contrasting the situation and the norm, it is evident that as a consequence of the social distance imposed by the authorities, no partially "in office" work was possible, but remained entirely confined into the home office boundaries.

This provision regarding a legal framework for the home office tasks that in the pre COVID-19 spectrum was somehow put under doubts, demonstrated to be at least some sort of tuition for the workers' rights. Bearing in mind that this modality was originally conceived as one that allowed sharing time between work and family, in this context 
functioned also to protect workers and their working positions among a vertiginously changing situation.

However, doctrine casts doubts in the usage of the institution, since as legally conceived, requires the agreement of the parties; while due to the emergency normative adopted in the emergency context, permits the resource to the smart working even in absence of the workers' agreement on that matter. (Alessi \& Vallauri, 2020:134-136)

As a preliminary conclusion, it seems evident and undeniable that due to the health crisis emerging in the country, the limits applied to several rights and liberties found a justification in the public health concerns. (Venanzoni, 2020:492-493) But a special attention is drawn to the fact that, in evaluating the measures and restrictions adopted by the State (national, regional, provincial and municipal), a process of balancing different liberties and weighting them in order to come up with a conclusion is the most concerning debate that could be now casted. Given different fundamental rights and liberties, with specific recognition in the Constitution and international agreements and treaties, all the rights find a ranking in which not all have the same relative importance.

On the other hand, the search for a constitutional fundamental supporting such limitations is not a simple activity. The path requires examining which is the "normative chain" that reunites all the laws, decrees, resolutions, dispositions, ordinances and rulings trying to search for common criteria in the underlying justifications. This has however, among the Italian constitutional jurisprudence, avoided since ever with certainty that a constitutional basis might exist. (Luciani, 2020:3-4)

Part of the doctrine has found in the principles of salus rei publicae and primum vivere, the key constitutional foundations from which all the derived legislation came from. (Licciardello, 2020:2; Luciani, 2020:2-4) On the other side, a critical view of the strict limits imposed to the population, especially regarding the movement and permanence, reunion, and summarizing the individual liberty, casts doubt about the mere and strictly formal analysis of a compilation of principles and facts showed as justifications to impose the so mentioned limits. (Venanzoni, 2020) These critical approaches also underline how dangerous could be, a permanent and infinite emergency status, as means to void fundamental rights with the fallacious emergency and exceptionality state of being.

\section{Dispositions at the different subnational levels and jurisdictional resolutions}

It might be important to underline that with subnational level, it is intended to mean all the State levels different from the national one. Therefore, some ordinances or legal dispositions enacted by Regions, Provinces and Municipalities will be briefly described, with the scope of showing to which extent different several rights were addressed, in some cases affecting them, and in some others, entering into competencies which were not in the head of these decentralized authorities.

According to the Italian Constitution, art. 114 provides that the Republic is composed by Municipalities, Provinces, Metropolitan Cities, the Regions and the [National] State. The first four mentioned, have autonomy and their own statutes, powers and functions which have to follow the principles set by the national Constitution. Art. 117 describes the competencies that only the [National] State has, from incise a) to s); while after that listing, 
describes which competencies are concurrent in matters of legislation, for which those powers are vested in the Regions with an exclusive exercise (Romano, 2020:5), except for the determination of the principles considered fundamental, which are attributed to the [National] State.

Therefore, according to the normative in force, Regions have the concurring competence to legislate in matters of protection and safety, health protection, sports, disaster relief, civil ports and airports, communications, transport, professions, and scientific research, among others. In this matter, the proposal is to analyze some dispositions enacted, firstly, by Regions, with a particular emphasis on the ones that were highly affected by the emergency.

In the special case of health related dispositions, it worth to mention that the legal foundation to do so, in the case of Regions, can be found not only in the Constitution, but also in Law 833/1978 from December 23rd. This law in art. 32.3.1, materializes the instrument by which the regional power can be exercised: the extraordinary and urgent ordinance. It provides that "(...) In the same matters [hygiene and public health] are issued by the president of the regional council (...) ordinances of a extraordinary and urgent nature, with effect extended (...) to the region or part of its territory including several municipalities (...)" If the nature of the emergency advises the adoption of a regional measure, then the DecreeLaw 112/1998 from march 31st has a special relevance at the time it gives special power to the Region to act by means of the previously mentioned ordinances.

Consequently, many regions enacted ordinances regarding different aspects of daily life in their respective communities. However, many of them interfered at some point with legislative State dispositions. But particularly, doctrine pronounces against the adoption of ordinances in the so mentioned conditions by the Regions, mostly considering the national impact of the pandemic. (Romano, 2020:3-5)

All Regions decided to enact ordinances, as well as some municipalities, with the aim or reduce the spread of the virus, many of them according to the competencies they have according to the legal framework in force. However, many others, especially the most affected ones since the beginning -Lombardy and Piemonte-, enacted dispositions that are worth to be briefly analyzed.

In the case of Lombardy, several dispositions were emanated in order to manage the COVID-19 emergency, some of them related to the protection of health. Specifically regarding this, one of the most striking ordinances, contained some recommendations about the steps needed to be taken in during the reopening activities, such as measuring the body temperature of employees and clients coming into shops, industries, etc., the use of masks and the use of an application called "AlertaLom" by the employer, which also means to compile a form named "CercaCovid" in a daily basis. In case of detecting temperatures over 37.5 Celsius degrees, the person shall not be admitted into the place in question and shall be informed to contact his or her general surgeon or personal doctor. From the jurisdictional side, not many decisions, now, were adopted by the Courts or Tribunals with a specific regard to the complex legal scheme derived from the emergency. Therefore, some decisions were adopted by Regional Administrative Courts (TAR), while on the other hand, some interpretations were done by the State Council, also part of the Administrative Justice with the constitutional burden of ensuring the legality of the Public 
Administration. In this section, therefore, two decisions from the TAR (one for Calabria, and one for Marche) will be briefly described.

The TAR for Calabria, ruled on March 28, 2020 , rejecting an appeal submitted against an ordinance emitted by the Municipality of Corigliano-Rossano (Calabria), which provided a sanitary surveillance with isolation at the residence of each citizen in the mentioned Municipality, from March 21st until April 3rd, 2020. The plaintiff also requested that the Ordinance from the Region of Calabria shall be voided.

In this ruling, the TAR-Calabria argued that in the comparison between, on the one side, the sanitary interest and on the other side, the commandment to remain "at home" and the right to work from an agricultural worker, the solution is that the public health interest shall prevail. In this regard, ruled that "in the current epidemic phase, when comparing of conflicting interests, having to give prevalence to the inherent public interest the protection of the health of the community and the need to stem any the risk of contagion, especially since the implied quarantine is underway and now carried out for more than half of its duration, expiring on April 3 P.V."

On the other hand, the TAR for Marche ruled on February 27th, 2020 , about the Ordinance 1/2020 from February 25th, emitted by the regional government that provided a series of suspension of activities, services, trips, among others even in absence of positive cases. To decide, the Court underlines that a measure adopted by the region, as consequence and derived from the dispositions contained in the Decree-Law that declared the emergency, cannot provide measures that constitute a wider affectation of rights and liberties, compared to the tools described by the mentioned Decree-Law.

\section{Political and security considerations around the measures: The relationship between danger and global health from an evolutionary perspective}

The relationship between danger (in general) and people's health is neither new, nor strictly linked to CODIV-19 emergency. This approach goes beyond the consideration of the individual health but has a wider spectrum whereas large groups of people are taken into consideration when talking about their health. These groups, commonly communities, could be cities, regions, countries, continents, and as learnt through the episodes of this 2020, the entire World. In this regard, the topic merges from a consideration of individual health to a public health issue which later will be linked to national and international security.

Public health has been conceptualized in different ways according to Historical periods. The firsts definitions during the 19th century were mainly centered in considering health as the absence of disease, reducing it to a biologist perspective; while during the first decades of the 20th century, Winslow conceptualized it saying that "( $p$ )ublic health is the science and art of preventing disease, prolonging life and promoting physical health and efficacy through organized community efforts for the sanitation of the environment, the control of communicable infections, the education of the individual in personal hygiene, the organization of medical and nursing services for the early diagnosis and preventive treatment of disease, and the development of social machinery which will ensure every individual in the community a standard of living adequate for the maintenance of health; so organizing these benefits in such a fashion as to enable every citizen to realize his birthright and longevity." (Koplan et al, 2009:1993) 
But right after saying this, it is important to underline some other concepts that have impact in the way the COVID-19 emergency was dealt. And it is to consider the evolution from the public health concept, traditionally attached to regions or states, to a wider concept which also incorporates the World/global spectrum: international health and global health.

While public health, as said, usually is attached to a country or region and deals with diseases and its prevention without requiring international cooperation, the notion of "international health" bursts into the scenery when a bilateral or multilateral cooperation is required to fight against health issues of the population. This concept has been traditionally linked to low and middle-income countries, and usually addresses the situations from a non-multidisciplinary perspective.

On the other hand, considering the impact of some health emergencies throughout History showed the importance of global cooperation, the "global health" emerges as a wider concept, not only considering a geographical aspect, but also the multidisciplinary that involves in itself. Therefore, the evolution from public health to global health has a direct impact in the way the COVID-19 emergency has been treated and how states, international organizations, private and public actors, and people in general, responded to its managing attempts. Notwithstanding this, global health should not only concentrate on pandemics and infectious diseases, but encompass also other aspects such as health workforce distribution, healthcare access for people of different parts of the globe, and research in the global health risks in order to anticipate, when possible, a health crisis.

However, health is not only attached to human life prolongation per se but has experienced an important development as part of security studies centered into the health problems as a threat to national security. Therefore, it seems much more coherent to analyze this COVID-19 crisis taking into consideration these two big disciplines, health, and security, while exploring their multiple interconnections that derive into the complex treatment of the emergency.

Arrived to this point, some important concepts can be extracted from the definitions provided above: a) prevention as the leading task; b) prolongation of life as scope; c) promotion of health in communities as a path to go from one to the other; d) global response as a must; e) healthcare access and health workforce distribution; f) the linkage between health and security. However, to deepen this topic specifically related to COVID emergency, it is mandatory to explore definitions about notions that came to our daily lives as a matter of normality: pandemic, infections, hygiene, medical or sanitary services, diagnosis, treatment, and naturally, death. Because death is the natural fact that represents the end of life, but also one of the situations that triggered most of the states' measures in the World.

A wide sector in the Italian doctrine, made reference to two transcendental principles from which many of the measures adopted by the different governmental institutions find justification: primum vivere and salus rei publicae (first to live, and health as a public thing or issue, respectively). These principles, at least primarily, seemed to be connected to the solidarity principle contained in the Italian Constitution, soon from art. 2. 
It has already been addressed the question of health care as a fundamental right, which relies on multiple levels of recognition and tuition, nationally and internationally. Therefore, at this stage it is possible to affirm that the Italian State from all levels of government, adopted tools and measures tending to avoid a faster spread of the virus also with the intention to protect the healthcare system that was set in jaque.

On another side of the situation, it is possible to identify the important role carried out by international organizations and agencies, particularly the World Health Organization (WHO) and the European Union. The WHO, as a specialized agency in the United Nations system, preferred the formulation of policies, rather than legislation (Biglinio \& Olmo, 2012:23) and in the case of the COVID-19 emergency; it had a cardinal importance in managing at a global level the crisis. After having triggered the global pandemic declaration, many other countries in the World followed the path of restricting activities as the only tool to diminish the risk of contagions, facing a virus that was about to challenge the infrastructure of all health care systems in the World.

In the case of the European Union, the answers given were mainly centered into the adoption of measures of coordination regarding travel and transportation, research, education, crisis, solidarity, and of course, health, being the main reason that triggered all the other actions. Therefore, it is possible to divide the initiatives into internal and external ones. In the first group can be found the measures regarding research for treatments and vaccines, information campaigns, and to some extent, the limitation of the virus spread. On the external side, the most transcendental measure was the border management measures, that included the ban to move as a consequence of the temporary close of borders (Goniewicz et al, 2020) while at the same time, several countries were imposing the same limitations, allowing only to certain people to enter into their territory (citizens or residents) requiring, in most of the cases, a mandatory isolation (quarantine) for a fourteen or fifteen days period.

Thus, a health-related problem, linked to the spread of a virus, soon turned to be a security problem. Multiple States adopted a series of measures that included the use of the public force and that triggered the criminal law system against those who defied the newly exceptional created norms. Therefore, in a very brief time, several normative created an emergency legal framework with strong powers given to the State to reinforce the decisions by means of criminalizing any activity not compatible with these new rules.

As seen in the case of the COVID-19 pandemic, not only a matter of public/international/ global health is in debate, but also a security issue that could be caused by the virus. How could the spread of the virus could be turned into a security problem in a very fast and burdensome way? Which were the measures and how were they adopted?

The answers to these questions require a brief explanation first regarding how a passage from security to another extreme version of it, the securitization, took place with the fight against the virus as an underlying motivation. Besides conspirative theories that became widely spread in the media, mostly in social networks with poor proof and lots of creativity, the fact is that the Government set strict limitations to several constitutional rights, liberties and guarantees. 
But what does securitization mean, and how did it affect rights and liberties? Barry Buzan, Ole Wæver and Jaap de Wilde created the notion of securitization to make reference to a situation that revolves around a threat to national security, and defined it as something that takes place when "a matter is presented as an existing threat, requiring emergency measures and they justify actions outside the limits of political procedure." (BUZAN et al., 1998:23-24) The two important axes in this matter are a) the threat, allegedly existing; and b) the extraordinary measures adopted in its name.

Recalling the Government first resolution of the Council of Ministers (CM) on January 31st which declared for the span of six months "[...] the status of emergency as a consequence of the associated health risk the onset of diseases deriving from transmissible viral agents" and correlating it with the Civil Protection Code (CPC), the measures that came after were strictly and publicly set under the umbrella given by Law, since as CPC states, there was an ongoing "[...] calamitous event(s) [...] which in due to their intensity or extent they must, immediately intervention, be faced with extraordinary means and powers [...]."

This urgency, and the shown risk that any delay in the adoption of measures usually fundament in the number of deaths, started to circulate among different circles, in the press, academy and public opinion, was deemed to prove the certainty and correctness of the measures. Notwithstanding this, to some extent, legal doctrine discussed one cardinal principle regarding any limitation or restriction to rights, liberties, and freedoms: proportionality.

However, even considering that the tools that governments enacted might have been disproportionate, the number of deaths was used as a fallacious reason to present the restrictions as the only possible way out of the danger zone. Until here, one of the requisites that needs to be fulfilled to consider that a situation was securitized, proves to be present: a matter presented as an actual threat, in this case, the threat was not only the health lives that could be lost, but also the complex structure of the State, that in situations like the present pandemic can be defied due to the multiple crises that derive from it (in the social fabric, economic sphere, and not to be left aside, the crisis of social values).

The other requisite that securitization demands, is the adoption of measures from an extraordinary perspective, aside from the political natural schemes. It cannot be denied that to enact the vast normative plexus, the Government used some constitutional attributions that allow setting ground for the emergency management. To negate this is an obvious way to tend to escape the reality but shall not be forgotten that one thing is to use the constitutional mechanisms and a different one is to abuse them.

In the crisis management overall situation, a set of dispositions implied the simple and plain denial of constitutional rights and freedoms with the purpose of reducing the risks of contagions and linked deaths, most of which obeyed comorbidity issues rather than only COVID-19 virus. Setting human lived loss as the other possible result if no restrictive measure was adopted, sounds closer to extorting the population than trying to protect it.

\section{Conclusion}

As intended with this brief article, the measures adopted by Italy, at different levels of government, implied a crisis management that assumed as the price for human health, a void of numerous fundamental rights. Not only because of a restriction to movements of 
people, or travelling, but in general due to the affectation of several constitutional rights that did not observe, in all the cases, the proportionality required by the fundamental law to restrict any right or liberty.

Thus, the right to receive health care was swiftly converted into the obligation to receive treatments to protect the wider value of life, wellbeing, and public health, fundamental to the solidarity principle. And not only that, but it also turned out to be the supreme value for which any price was admitted to be fairly paid, even if the price meant to restrict all the other rights a human being could have.

From another perspective, it also created the grounds for antecedents regarding the crisis management, and particularly the emergency framework that allowed different spheres of government, to adopt measures that were proven to be invasive to the citizens' and residents' lives in the country. Due to the recourse to exceptional tools constitutionally admitted by the constituted powers of the country, and the fallacious recourse to reasons that were presented as the fundamentals of those decisions, once again health was presented as a matter of security, and was therefore securitized.

It is undeniable that a mere spectator role for the State would have caused even a more despicable result because it is not possible to deny the reality. What are however doubtful, are the grounds presented for the adoption of all the different chosen paths, and even more questionable, the extension of the restrictions that led to a new set of crimes against the public order amid a pandemic situation that was already stressful and critical for the people in their every day basis.

\section{BIBLIOGRAPHY AND OTHER RESOURCES}

- ALESSI, Cristina and VALLAURI, Maria Luisa (2020): /l lavoro agile alla prova del COVID-19. In BONARDI, Olivia, CARABELLI, Umberto, D'ONGHIA, Madia and ZOPPOLI, Lorenzo (2020): COVID-19 e diritti dei lavoratori, Ediesse, Roma.

- BIGLINO, Irene, and OLMO, Anthony (2012): La salute come diritto fondamentale: una ricerca sui migranti a Torino. In Rapporti di ricerca LDF n. 1, 2012.

- BROWN, Theodore M.; CUETO, Marcos; y FEE, Elizabeth (2006): The World Health Organization and the Transition From "International" to "Global" Public Health. In American Journal of Public Health, vol. 96 n. 1, pp.62-72.

- BUZAN, Barry; WÆVER, Ole; DE WILDE, Jaap (1998): Security: A new framework for analysis, London, Lynne Rienner Publishers, pp. 23-24

- CIVIL PROTECTION DEPARTMENT (2020): Emergenza Coronavirus - Mappa della Situazione. Retrieved on August 2nd, 2020 from <http://www.protezionecivile.gov.it/>

- CTV NEWS (2020): Several Italian Mafia bosses released from prison over coronavirus fears. Retrieved on May 5th, 2020 from <https://www.ctvnews.ca/world/several-italian-mafiabosses-released-from-prison-over-coronavirus-fears-1.4912371>

- EUROPEAN UNION (2000): Charter Of Fundamental Rights of the European Union. In Official Journal of the European Union from October 26th, 2012, with the adapted version according to the Treaty of Lisbon wording. 
- GONIEWICZ Krzysztof; KHORRAM-MANESH Amir; HERTELENDY Attila J.; GONIEWICZ, Mariusz; NAYLOR Katarzyna \& NAYLOR, Frederick M. BURKLE, Jr. (2020): Current Response and Management Decisions of the European Union to the COVID-19 Outbreak: A Review. In Sustainability, n. 12, retrieved on June 10th, 2020 from < https://www.mdpi.com/20711050/12/9/3838\#cite >.

- HART, Herbert L. A. (1961): The concept of Law. Clarendon Law Series, Oxford.

- HASENCLEVER, Andreas; MAYER, Peter; RITTBERGER, Volker; MURILLO, Lorena; y CASTRO Y ORTIZ, Francisco J.J. (1999): Las teorías de los regímenes internacionales: situación actual y propuestas para una síntesis, Foro Internacional, Vol. XXXXIX, No. 4 (158) (OctubreDiciembre 1999), pp. 499-526.

- HELD, David; y McGREW, Anthony (2002): Governing Globalization. Power, Authority and Global Governance, Cambridge, Polity Press.

- INTERNATIONAL CONFERENCE ON PRIMARY HEALTH CARE (1978): Declaration of Alma-Ata.

- ISTITUTO NAZIONALE DI STATISTICA (2020a): Indicatori demografici 2019. Retrieved on July 17th, 2020 from <https://www.istat.it/it/files//2020/02/Indicatori-demografici_2019.pdf>

- ISTITUTO NAZIONALE DI STATISTICA (2020b): Impatto Dell'epidemia Covid-19 Sulla Mortalità: Cause Di Morte Nei Deceduti Positivi A Sars-cov-2. Retrieved on July 19th, 2020 from <https://www.istat.it/it/files//2020/07/Report_ISS_Istat_Cause-di-morte-Covid.pdf>

- ISTITUTO NAZIONALE DI STATISTICA (2020c): Rapporto annuale 2020. La situazione del Paese. Report presented on July 3rd, 2020 in Montecitorio Palace, Rome. Retrieved on July 10th, 2020 from <https://www.istat.it/it/archivio/244392>

- ISTITUTO NAZIONALE DI STATISTICA (2020d): I/ quarter 2020. Preliminary Estimate of GDP, published on July 31st, 2020. Retrieved on August 1st, 2020 from <https://www.istat.it/it/ files//2020/07/FLASH_20q2_EN.pdf>

- ISTITUTO NAZIONALE DI STATISTICA (2020e): DATI STATISTICI PER IL TERRITORIO, published on May 27th, 2020. Retrieved on August 1st, 2020 from <https://www.istat.it/it/archivio/243448>

- ISTITUTO NAZIONALE DI STATISTICA (2020f): Anziani.Stat. Dati e indicatori sull-invecchiamento della popolazione in Italia,. Retrieved on August 1st, 2020 from <http://dati-anziani. istat.it/\#>

- ISTITUTO NAZIONALE DI STATISTICA (2020g): Computers and Tablets in the Italian Households. Years 2018/2019. Retrieved on August 1st, 2020 from <https://www.istat.it/en/ archivio/242572>

- ITALIAN REPUBLIC - MINISTRY OF HEALTH (2020): Ordinance form January 25th, 2020 regarding "Prophylactic measures against the new Coronavirus (2019 - nCoV). (20A00618). OJ General Series n.21 of 27-01-2020", published in the Italian Official Journal on January 27th, 2020.

- ITALIAN REPUBLIC - MINISTRY OF HEALTH (2020): Ordinance form January 30th, 2020 regarding "Prophylactic measures against the new Coronavirus (2019 - nCoV). (20A00738). OJ General Series n.26 of 01-02-2020", published in the Italian Official Journal on February 1 st, 2020.

- ITALIAN REPUBLIC - COUNCIL OF MINISTERS (2020): Dichiarazione dello stato di emergen$z a$ in conseguenza del rischio sanitario connesso all'insorgenza di patologie derivanti da agenti virali trasmissibili. Published in the Official Journal on February 1st, 2020. Retrieved on April 4th, 2020 from <https://www.gazzettaufficiale.it/eli/id/2020/02/01/20A00737/ sg>

- ITALIAN REPUBLIC - COUNCIL OF MINISTERS (2020): Resolution of January 31st, 2020. Dichiarazione dello stato di emergenza in conseguenza del rischio sanitario connesso all'insorgenza di patologie derivanti da agenti virali trasmissibili. (20A00737). Official Journal 
of the Italian Republic, February 1st, 2020.

- ITALIAN REPUBLIC - LAW 833/1978 FROM 23TH DECEMBER(1978): Istituzione del Servizio Sanitario Nazionale. Published in the Official Journal December 28th, 1978.

- ITALIAN REPUBLIC - MINISTRY OF PUBLIC INSTRUCTION (2020): Note 288/2020 of March 17th. Retrieved on April 17th 2020 from <https://www.miur.gov.it/documents/20182/0/ Nota+prot.+388+del+17+marzo+2020.pdf/d6acc6a2-1505-9439-a9b4-735942369994?ve rsion $=1.0 \& \mathrm{t}=1584474278499>$

- ITALIAN REPUBLIC - REGIONAL ADMINISTRATIVE COURT FOR CALABRIA (2020): Decreto del Presidente del Tribunale Amministrativo Regionale per la Calabria, Sezione Prima, sul ricorso 359/2020 contro il Comune di Corigliano-Rossano. Retrieved on July 16th, 2020, from $<$ https://www.federalismi.it/ApplOpenFilePDF.cfm?artid=41779\&dpath=document\&dfi le $=05042020114723$.pdf\&content $=$ TAR\%2B\%2BCALABRIA\%2C\%2B\%2B\%2BDecreto\%2B n\%2E\%2B165\%2F2020\%2C\%2BComparazione\%2Btra\%2Binteresse\%2Bsanitario\%2Bsot teso\%2Ball\%27obbligo\%2Bdi\%2Bpermanere\%2Bin\%2Bcasa\%2Be\%2Binteresse\%2Ba\%2 Blavorare\%2Bdi\%2Bun\%2Bbracciante\%2Bagricolo\%2E\%2BTAR\%2BCatanzaro\%2B\%2D\% 2Bstato\%2B\%2D\%2Bdocumentazione\%2B\%2D\%2B>

- ITALIAN REPUBLIC - REGIONAL ADMINISTRATIVE COURT FOR MARCHE (2020): Decreto del Presidente del Tribunale Amministrativo Regionale per le Marche, Sezione Prima, sul ricorso 118/2020 contro la Regione delle Marche, Presidente della Giunta Regionale. Retrieved on July 16th, 2020, from <https://www.federalismi.it/ApplOpenFilePDF.cfm?artid=41315\&d path=document \&dfile $=19032020111056$. pdf \& content $=$ TAR\%2B\%2BMARCHE\%2C\%2B\% 2B\%2BDecreto\%2Bn\%2E\%2B118\%2BDecreto\%2BTAR\%2BMarche\%2Bannullamento\%2 Bdell\%27ordinanza\%2Bn\%2E\%2B1\%2Bdel\%2B25\%2F02\%2F2020\%2Bdel\%2BPresidente \%2BRegione\%2BMarche\%2B\%2D\%2Bstato\%2B\%2D\%2Bdocumentazione\%2B\%2D\%2B> - ITALIAN REPUBLIC (2017): Law 81/2017: Misure per la tutela del lavoro autonomo non imprenditoriale e misure volte a favorire l'articolazione flessibile nei tempi e nei luoghi del lavoro subordinato. (17G00096), published in the Official Journal of June 13th, 2017, Retrieved on April 17th, 2020 from <https://www.gazzettaufficiale.it/eli/id/2017/06/13/17G00096/sg>

- ITALIAN REPUBLIC (2018): Legis/ative Decree n. 1, from January 2nd, 2018 (Civil Protection Code). Retrieved on April 17th 2020 from <http://www.protezionecivile.gov.it/amministrazione-trasparente/provvedimenti/dettaglio/-/asset_publisher/default/content/decreto-legislativo-del-6-2-2020-disposizioni-integrative-e-correttive-del-decreto-legislativo2-gennaio-2018-recante-codice-della-protezione-civile->

- ITALIAN REPUBLIC (2020): Decree-Law 18/2020 from March 17th. Retrieved on April 16th, 2020 from <https://www.gazzettaufficiale.it/eli/id/2020/03/17/20G00034/sg>

- ITALIAN REPUBLIC -PENITENTIARY ADMINISTRATION DEPARTMENT (2020): Note n. 95907 of March 21st, 2020. Retrieved on April 17th 2020 from <http://www.ristretti.it/commenti/2020/aprile/pdf9/circolare_dap_21_marzo.pdf>

- ITALIAN REPUBLIC -PENITENTIARY ADMINISTRATION DEPARTMENT (2020): Note $n$. 209709 from June 16th, 2020. Retrieved on April 17th 2020 from <https://www.penitenziaria.it/public/circolare_dap_sospensione_21_marzo_2020_.pdf>

- JAEGER, Hans-Martin (2010): UN reform, biopolitics, and global governmentality. In International theory, Vol. 2, No. 1, pp. 50-86.

- KOPLAN, Jeffrey P.; BOND, T. Christopher; MERSON, Michael H.; REDDY, K. Srinath; RODRÍGUEZ, Mario Henry; SEWANKAMBO, Nelson K.; WASS, Judith N Wass (2009): Towards a common definition of global health. In Lancet, 373, pp. 1993-1995.

- KUTZIN, Joseph (2013): Health financing for universal coverage and health system performance: concepts and implications for policy. In Bull World Health Organ 2013:91, pp. 602611 
- L'ESPRESSO (2020): Esclusivo: coronavirus, i mafiosi al 41 bis lasciano il carcere e tornano a casa. Retrieved on May 5th, 2020 from <https://espresso.repubblica.it/attualita/2020/04/21/news/capimafia-lasciano-il-carcere-coronavirus-1.347378>

- LICCIARDELLO, Sebastiano (2020): I poteri necessitati al tempo della pandemia. Retrieved on June 12th, from <https://www.federalismi.it/nv14/articolo-documento.cfm?Artid=43524> - LÓPEZ SANTOS, V.; y FRÍAS OSUNA, A. (2000): Concepto de Salud Pública. In FRÍAS OSUNA, A.: Salud Pública y educación para la salud, Barcelona, Editorial Masson, p. 3-13.

- LUCIANI, Massimo (2020): Il sistema delle fonti del diritto alla prova dell'emergenza. In Liber amicorum per Pasquale Costanzo, 2020, p. 4.

- MANCHOLA CASTILLO, Camilo Hernán; GARRAFA, Volnei; CUNHA, Thiago y HELLMANN, Fernando (2017): El acceso a la salud como derecho humano en políticas internacionales: reflexiones críticas y desafíos contemporáneos. In Ciência \& Saúde Coletiva, 22(7), pp. 2151 2160.

- MERRIAM-WEBSTER (2020): Merriam-Webster Dictionary. Retrieved on April 22nd, 2020 from <https://www.merriam-webster.com/dictionary/emergency>

- MERSON, Michael H.; BLACK, Robert E.; y MILLS, Anne J. (2012): International public health: diseases, programs, systems, and policies, 3a Edición, Jones and Barlett Publishers, P. xvi..

- MIELE, Giovanni (1936): Le situazioni di necessità dello Stato. In Archivio di diritto pubblico, n. I, pp. 377-455.

- NINO, Carlos Santiago (2003): Introducción al análisis del derecho. 2nd Edition, 12th reprint, Astrea, Buenos Aires.

- PROGRAMA DE NACIONES UNIDAS PARA EL DESARROLLO (1994): Informe para el Desarrollo Humano, México D.F., Fondo de Cultura Económica S.A. de C.V.

- REGION OF LOMBARDY (2020): Ordinance no. 546/2020, Additional measures for the prevention and management of the epidemiological emergency from COVID-10. Published in the Official Journal of the Region of Lombardy, n. 134.

- ROLLA, Giancarlo (2015): Profili Costituzionali dell-emergenza. In Rivista dell'Associazione Italiana dei Costituzionalisti, n. 2, pp. 1-26.

- ROMANO, Andrea (2020): I rapporti tra ordinanze sanitarie regionali e atti statali normativi e regolamentari al tempo del Covid-19. Retrieved on June 12th, 2020 from <https://www.federalismi.it/ApplOpenFilePDF.cfm?artid=43499\&dpath=document\&dfile=19052020153048. pdf\&content=l\%2Brapporti\%2Btra\%2Bordinanze\%2Bsanitarie\%2Bregionali\%2Be\%2Batti \%2Bstatali\%2Bnormativi\%2Be\%2Bregolamentari\%2Bal\%2Btempo\%2Bdel\%2BCovid\%2D 19\%2B\%2D\%2Bstato\%2B\%2D\%2Bpaper\%2B\%2D\%2B>.

- SENATE OF THE ITALIAN REPUBLIC (2020): Constitution of the Italian Republic. Parliamentary Information, Archives and Publications Office of the Senate Service for Official Reports and Communication. Retrieved on May 25th, 2020 from <https://www.senato.it/documenti/ repository/istituzione/costituzione_inglese.pdf>

- STUCKER, David; FEIGL, Andrea B.; BASU, Sanjay y McKEE, Martin (2010): The political economy of universal health coverage. Working document for the First Global Symposium in Healthcare Systems Research, Montreux, Switzerland.

- UNITED NATIONS (1948): Universal Declaration of Human Rights. Retrieved on April 22nd, 2020 from <https://www.un.org/en/universal-declaration-human-rights/>

- VENANZONI, Andrea (2020): L'innominabile attuale. L'emergenza Covid-19 tra diritti fondamentali e stato di eccezione. In Forum di Quaderni Costituzionali, 1, 2020. Retrieved on July 10th, 2020 from <www.forumcostituzionale.it>

- WENDT, Alexander (1992): Anarchy is what States Make of it: The Social Construction of Power Politics. In International Organization, Vol. 46, No. 2 (Primavera, 1992), pp. 391-425.

-WINSLOW, C. .-E. A (1920): The Untilled Fields of Public Health. In Science, New Series, Vol. 
51, No. 1306, American Association for the Advancement of Science, pp. 23-33.

- WORLD HEALTH ORGANIZATION (2015): Descriptive Note $N^{\circ} 323$ "Health and Human Rights". Retrieved on October 17, 2017 from <http://www.who.int/mediacentre/factsheets/fs323/es/>.

- WORLD HEALTH ORGANIZATION (2020): Statement on the second meeting of the International Health Regulations (2005) Emergency Committee regarding the outbreak of novel coronavirus (2019-nCoV). Retrieved on May 5th, 2020, from <https://www.who.int/news-room/ detail/30-01-2020-statement-on-the-second-meeting-of-the-international-health-regulations-(2005)-emergency-committee-regarding-the-outbreak-of-novel-coronavirus-(2019ncov)>. 